The Economic Journal, 110 (November), F672-F694. (C) Royal Economic Society 2000. Published by Blackwell Publishers, 108 Cowley Road, Oxford OX4 1JF, UK and 350 Main Street, Malden, MA 02148, USA.

\title{
UNNATURAL EXPERIMENTS? ESTIMATING THE INCIDENCE OF ENDOGENOUS POLICIES*
}

\author{
Timothy Besley and Anne Case
}

\begin{abstract}
There are numerous empirical studies that exploit variation in policies over space and time in the U.S. federal system. If state policy making is purposeful action, responsive to economic and political conditions within the state, then it is necessary to identify and control for the forces that lead to these policy changes. This paper investigates the implications of policy endogeneity for a specific policy context - workers' compensation benefits. We contrast different methods of estimation and their pros and cons in this context.
\end{abstract}

To estimate the effect of policies on economic behaviour, one needs a source of policy variation. It has long been recognised that the spatial and temporal variation in laws afforded by a federal system holds great potential for estimating the effect of government policies on economic outcomes. However, timevarying state level policies can be studied as either left or right hand side variables. Indeed, there is a political economy literature that addresses the determinants of state policy variation where the policies are themselves taken as outcomes of interest. ${ }^{1}$ If state policy making is purposeful action, responsive to economic and political conditions within the state, then it may be necessary to identify and control for the forces that lead policies to change if one wishes to obtain unbiased estimates of a policy's incidence. This paper compares different methods used in incidence analysis to exploit variation in state policy, and contrasts the ability of these methods to deal adequately with the consequences of policy endogeneity. We hope to clarify when it is reasonable to treat differences in state laws as 'natural experiments', a term increasingly used to describe exercises that exploit cross-state policy variation. ${ }^{2}$

Our investigation is focused on a particular policy choice. Workers' compensation insurance is a state-based programme that provides medical expense reimbursement and indemnity payments for losses incurred as a result of jobrelated injury, illness or disease. ${ }^{3}$ We choose to analyse it for a number of reasons. The political economy of such policies is real and interesting. In addition, there is significant variation in policy choice over time and across

* We are grateful to David Card, Angus Deaton, Alan Krueger, Robin Lumsdaine, Bruce Meyer, Christina Paxson and seminar participants at many institutions for helpful comments and discussions. We thank Loic Sadoulet, Elizabeth McClemens, and Elizabeth Schaefer for valuable research assistance. Financial support was provided by the NSF [NSF SBR93-20894].

1 For example, Besley and Case $(1995 a, b)$ consider the impact of the political process on state taxes, mandates, and policies. Poterba (1994) shows how state political conditions affect policy outcomes during times of fiscal stress.

2 In this literature, a 'natural experiment' is often implicitly defined as a law change that affects outcomes for identifiable individuals who are otherwise indistinguishable from those not directly affected by the law change. 'Natural experiments' thus have natural control groups with which to compare outcomes. For a discussion of the issues surrounding natural experiments, see Meyer (1995).

3 For an overview of workers' compensation legislation in this century, see Chelius (1977) and Berkowitz and Berkowitz (1985). An earlier study of the determination of workers' compensation benefits is provided by Danzon (1993). 
states, suggesting that this may be an interesting area in which to estimate policy incidence. Changes in workers' compensation benefits are also likely to influence most heavily the outcomes for workers in certain identifiable industries and occupations.

The paper views the relative merits of different incidence estimators for this example. Although some of the theoretical claims made are general, the relevance and magnitude of the concerns raised here may be specific to the example chosen. However, the analysis illustrates why it may be important to consider the implications of policy endogeneity more generally.

Many authors who put policies on the right are doubtless aware of the possibility of endogeneity and, in earlier cross-sectional studies, it was common to look for an instrumental variable in an attempt to deal with this. The advent of studies that use a panel of states over time has moved such issues away from centre stage. Many panel data studies, some of which are reviewed below, use a cross-state fixed effect analysis, where the researcher includes a state fixed effect to control for permanent differences across states in policies and outcomes. If the systematic determinants of state policies are additive, time invariant state characteristics, then this will indeed remove concerns about endogeneity. ${ }^{4}$ Below, we consider the validity of such a claim for the example of workers' compensation benefits.

Incidence analysis using control groups, either within or across states, have become increasingly popular and appear to offer a clean way of identifying the effect of a policy. Outcomes between groups are compared before and after a law change. A 'treatment' group is selected that is directly affected by the policy change. The researcher also selects a 'control' group, either from other states or a different group of individuals within a state. The effect of the policy is then estimated from the difference in the outcomes for these two groups. This is frequently known as 'differences-in-differences' estimation. It is sometimes stated that this procedure protects the analysis from bias that policy endogeneity might cause. We show that the theoretical implications of policy endogeneity for this approach are somewhat more subtle, and again we illustrate findings using workers' compensation benefits.

There are many studies of the general kind being considered here. Recent work using cross-state fixed effects estimation includes work by Anderson and Meyer (1997), who use firm-level variation in tax rates, due in part to policy differences between eight states over time, to explore the effect of firms' unemployment insurance tax rates on firm employment and worker earnings. Within this framework, Gruber and Madrian (1997) estimate the effect of state laws mandating continued access to employer provided insurance after job separation on the probability of job separation and on the probability of continued non-employment following job-leaving. Blank et al. (1996) estimate the impact of state abortion laws on state abortion rates, controlling for state characteristics, state fixed effects and year effects. Miller et al. (1994) estimate

${ }^{4}$ See, for example, Pitt et al. (1993) and Rosenzweig and Wolpin (1986).

(C) Royal Economic Society 2000 
the effect of changes in state child support laws on child support payments received, controlling for state effects and year indicators.

In the latter two papers, authors report finding unexpected results. For example, Blank et al. find that laws that are passed but enjoined have almost as large an effect on in-state abortion rates as laws that are enforceable. Miller $e t$ $a l$. find that two policies designed to make it easier to obtain a child support award - expedited processes and publicised services - appear to reduce the probability of obtaining a child support award. As we will discuss below, policy endogeneity may help to explain such results.

Micklewright and Nagy (1996) examine the impact of changes in unemployment insurance benefits on the length on unemployment spells in Hungary. Their 'experimental' group are people who applied for benefits after the law changed, and as their 'control,' those who lost jobs prior to the law change and who were grandfathered under old rules. Chiappori et al. (1998) analyse the demand for physician services upon the introduction by a firm's insurer of a copayment for expenses, at a point in time when government insurance became less generous. They choose as a 'control' group individuals whose firms chose to contract with insurers who did not introduce such a copayment. Chiappori et al. (1998) note that their 'treatment' group is significantly older than their 'control' group, and contains a higher proportion of elderly people (65 and older), leading to questions about why certain firms chose certain insurers. Meyer et al. (1995) estimate the impact of changes in workers' compensation benefit caps on injury duration. They take as their "experimental' groups high wage earners who were previously affected by the maximum benefit cap, and use as a 'control' group those low wage earners who were not previously affected by the cap. In what follows, we will discuss ways in which policy endogeneity may affect the adequacy of within-state control groups.

Also gaining popularity are differences-in-differences estimation strategies in which a set of states, unaffected by the policy, are chosen as 'controls.' Several recent papers on minimum wages have made use of this method. For example, Card (1992) estimates the incidence of an increase in California's minimum wage law by comparing the change in the employment to population ratio for teens in California to those in Arizona, New Mexico, Florida, Georgia and the region of Dallas-Fort Worth, Texas. Ruhm (1996) examines the impact of parental leave mandates in 16 European countries by comparing the labour market outcomes of women in 'experimental' countries, which raised paid leave entitlements during a calendar year, to those of women in 'non-experimental' countries, which did not. We will explore below the extent to which recognition of policy endogeneity affects incidence estimation based on a small set of control states.

Overall, our analysis highlights two main issues. First, investigating the determinants of policies is an important prerequisite to understanding when and whether one can legitimately put policy on the right hand side. If interstate variation in policy is to be useful in estimating the impact of a policy change on an identifiable group, the source of the policy variation must be fully understood by the researcher. This is a necessary, but not sufficient, 
condition for unbiased estimation of a policy's effects. It must also be the case that control groups are stable, and adequately reflect the effect of changes in other variables that are simultaneously influencing outcomes of the group under study. This will be made plain in the examples presented below.

On the positive side, we think that modeling the political economy of policy choice presents a useful way forward. First, it gives us a basis for selecting 'control groups' with which to measure the effect of policy change. Good control groups will be those whose fortunes have evolved similarly to the those of the group experiencing the policy change and who respond similarly to changes in the variables that drive policies to change. It also allows for the identification of instruments for the policy change. Overall, our conclusion is for a return to an older issue in public finance, the need to understand where policy comes from as part of estimating its incidence.

The remainder of the paper is organised as follows. We begin by providing a theoretical framework to describe the incidence and evolution of a particular policy, workers' compensation benefits. We then estimate the determinants of workers' compensation benefits over the period 1975-90. We show that state economic and demographic changes, together with changes in political representation in the state, drive changes in workers' compensation benefits during this period. We then explore the implications of this finding for crossstate fixed effect estimation and differences-in-differences estimation.

We propose a possible procedure for handling some cases where there are concerns about policy endogeneity. The analysis exploits the fact that women's involvement in the political process has an effect on policy making, a point well documented in the political science literature and in the popular press. ${ }^{5}$ We argue that in those cases in which women's political involvement affects outcomes but is not itself driven by the outcome, it may be a useful instrument for policy choice.

\section{Framework}

It is interesting to begin by thinking why the government may choose to intervene in the provision of workers' compensation. Clearly it is central to the policy's endogeneity that we view policy makers as pursuing well-defined ends. That production processes involve a risk of worker injury yields no necessary reason why government intervention is warranted. First, the employee who is injured may resort to the tort system to gain redress for work place injuries. Assuming that the tort system is efficient, then this will provide an efficient solution. The historical literature suggests that movement toward the present system was due in part to worker and firm beliefs that the tort system was unnecessarily cumbersome for settling many cases. This is quite natural if litigation is costly, although need not imply any inefficiency if the plaintiff is made truly whole in the process. The lawyers might capture transfers, however this does not imply that tort is inefficient. On this view, however, there is no

5 See, for example, Thomas (1994) or Rule and Zimmerman (1994).

(C) Royal Economic Society 2000 
reason to believe that the state is necessary. Voluntary provision should work just as well as any kind of mandating.

A second class of problems with using a tort and liability system of redress is the possibility of imperfect information on the part of workers. This has been analysed previously by Diamond (1977) and Viscusi (1980), on whose treatments we build our theoretical discussion. The basic idea is that workers do not know the true probability of an accident occurring, while this is known to firms and to the government. In this world, a government can raise labour's expected utility by increasing the benefits to injured workers who receive too little insurance coverage.

We will consider a firm (or group of identical firms) who use a production technology that puts workers at risk on the job. We suppose, in particular, that a worker faces a probability $\theta$ of having an accident. The firm can insure the worker actuarially fairly, so that if the benefits that it pays in the event of an accident are $c$, standing for 'compensation', then its premium is $\theta c$. Labour costs per worker thus consist of two things, a wage $w$ and the actuarial cost of accident insurance. Normalising its output price to one, the firm's profits are thus

$$
F(L)-(w+\theta c) L
$$

Workers must be compensated for working for the firm. We suppose that they could get utility of $u$ working elsewhere. The worker's perception that he will be injured on the job is $\hat{\theta}$. Thus his expected utility is

$$
(1-\hat{\theta}) u(w)+\hat{\theta} v(w+c)
$$

where we have supposed that his utility function is $u(\cdot)$ if no accident occurs and $v(\cdot)$ otherwise. The firm must ensure that it offers the worker a package of wages and compensation so that (2) is greater than or equal to $u$. The firm choose three things $(L, w, c)$. This can be solved in two stages, first choosing $(w, c)$ to minimise unit labour costs and then choosing $L$ to maximise profits.

If the worker's participation constraint holds with equality, then (2) will equal to $u$ and we can solve for the wage that the firm will offer for any level of compensation, denoted by $w=h(u, c, \hat{\theta})$. The firm then solves

$$
W(u, \theta, \hat{\theta})=\operatorname{Min}_{c}[h(u, c, \hat{\theta})+\theta c] .
$$

We work with the case where $\hat{\theta}<\theta$ (workers tend to underestimate the danger of an accident). This implies that the firm will under-insure workers, i.e., $u^{\prime}(w)<v^{\prime}(w+c) .^{6}$ The firm's labour demand satisfies $F^{\prime}(L)=W(u, \theta, \hat{\theta})$.

If the government is paternalistic, it evaluates the well-being workers at the 'true' probability of an accident - i.e., with a utility function $(1-\theta) u(w)+$ $\theta v(w+c)$. Thus it recognises that workers are under-insured and can legislate an increase in compensation above the level that the firm would offer. This will

${ }^{6}$ If $\hat{\theta}=\theta$ then the compensation will be set so that $u^{\prime}(w)=v^{\prime}(w+c)-$ the standard optimal insurance result.

(C) Royal Economic Society 2000 
lead to lower wages as the firm keeps workers at $u$. However, even so, workers gain. ${ }^{7}$ This creates a rationale for intervention.

A mandate higher than the firm's desired level raises the firm's unit labour costs and leads to a reduction in labour demand. At the industry level, it may also change $u$. Thus we expect, ignoring other equilibrium effects, that employment in the risky sector will contract as a result of the benefit mandate.

Now consider the optimal provision of mandates. We do so in a simple context where policy makers attach a weight of $\lambda$ to capitalists and a weight of $(1-\lambda)$ to workers, yielding an objective function:

$$
\lambda \Pi(c, u, \theta, \hat{\theta})+(1-\lambda)\{L(c, u, \theta, \hat{\theta}) V(c, u, \theta, \hat{\theta})+[N-L(c, u, \theta, \hat{\theta})] u\},
$$

where $\Pi(c, u, \theta, \hat{\theta})=\operatorname{Max}\{F(L)-[h(u, c, \hat{\theta})+\theta c] L\}$, and $L(c, u, \theta, \hat{\theta})$ is the arg max in the previous equation and $V(c, u, \theta, \hat{\theta})=\theta v[h(u, c, \hat{\theta})+c]$ $+(1-\theta) u[h(u, c, \hat{\theta})]$. In general, we can write the solution to maximising this as

$$
c^{*}=f(\lambda, u, \theta, \hat{\theta}) \text {. }
$$

This equation is a useful starting point for the empirical modelling. We expect that the optimal policy choice will reflect political variables, here represented by $\lambda$, economic variables, here represented by $u$, and variables that reflect the extent of the market failure or redistribution problem that the policy is solving, here represented by $(\theta, \hat{\theta})$.

For wages or employment, we can also study the equations $L(c, u, \theta, \hat{\theta})$ and $w=h(c, u, \hat{\theta})$ directly. To get at industry wide effects, let $S(u)$ be the willingness of labourers to work in the sector as a function of the utility that they obtain there. Also let $\eta^{S} \equiv \partial \log S(u) / \partial \log u$ be the elasticity of labour supply with respect to the wage. Then $u$ is determined by $L[h(u, c, \hat{\theta})+\theta c]=S(u)$. Defining $\eta^{D} \equiv-\partial \log \{L[h(u, c, u)+\theta c]\} / \partial \log u$ as the elasticity of labour demand with respect to the reservation utility levels, then it is straightforward to show that

$$
\frac{d w}{d(\theta c)}=-\frac{\eta^{D}+\alpha \eta^{S}}{\eta^{D}+\eta^{S}}
$$

where $\alpha \equiv-\partial h(u, c, \hat{\theta}) / \partial c$. This is similar to a result in Gruber and Krueger (1991). This says that the change in the wage depends upon the extent to which there is a divergence between the marginal valuation of worker and the firm.

\section{Empirical Models}

Our policy variable is the insurance rate that firms are initially charged to hire a worker in a specific industry/occupation. These rates, known as manual

7 It is easy to check that

$$
\frac{d[(1-\theta) u(w)+\theta v(w+c)]}{d c}=u^{\prime}(w) \theta\left(\frac{\theta-\hat{\theta}}{\hat{\theta}}\right)>0 .
$$

(C) Royal Economic Society 2000 
rates, are an approximate measure of the actuarial cost of providing benefits for a given activity. ${ }^{8}$ They are only an approximation, however, because of experience rating, premium discounts, and dividends. Nonetheless, they are widely viewed as the most reliable indicator of government policy in this area. Gruber and Krueger (1991) report a correlation of 0.85 between average manual rates and average manual rates adjusted to reflect these deviations. These rates, which are expressed as a percentage of payroll, vary considerably within industry/occupation between states and over time, which should in turn affect the cost of hiring workers.

Here, we focus on one set of manual rates: those paid for workers in concrete construction. These data are plotted in Fig. 1 by state. There are a few unavoidable gaps in the data-for example, no evidence is available for Nevada, Washington State, or Wyoming. However, these data provide as close to a complete picture on state manual rates for concrete construction for this period as we believe is possible to obtain. Fig. 1 shows that there is a good deal of variation in the rates paid across states and over time. We investigate the impact of changes in manual rates on two outcomes: employment and average hourly earnings in the construction industry.

Equation (4) led us to believe that programme generosity should respond to changes in state economic, demographic and political variables. We explore the determinants of state workers' compensation benefits by regressing our policy measure on state economic conditions, state population and proportion elderly, and indicators of political power within the state.

Let $P_{s t}$ represent our measure of workers' compensation benefits in state $s$ at time $t$. We estimate an equation of the form

$$
P_{s t}=\beta_{t}+\psi_{s}+\mathbf{Q}_{s t} \boldsymbol{\phi}+\mathbf{W}_{s t} \boldsymbol{\zeta}+v_{s t},
$$

where $\beta_{t}$ is a year effect and $\psi_{s}$ is a state fixed effect. The vector $\mathbf{Q}_{s t}$ is a $\left[1 \times k_{1}\right]$ set of time-varying state level economic variables that includes state income per capita (1982 dollars), the state employment-population ratio, the state unemployment rate, state population and proportion of state population above the age of 65 .

The vector $\mathbf{W}_{s t}$ is a $\left[1 \times k_{2}\right]$ set political variables. The political variables we focus on are number of legislators, and the number of women legislators, in state lower and upper houses over this period. Recent studies conducted by the Center for the American Woman and Politics at Rutgers University found that 'women were more likely to give priority to public policies related to their traditional roles as care givers in the family and society-e.g., policies dealing with children and families and health care. ${ }^{9}$ Thomas (1994) finds significant differences in the legislative priorities of men and women. There is a wide-

\footnotetext{
8 These data were made available to us for the 1975-88 period through the generosity of Timothy Schmidle and John Burton Jr.

9 Source: 'The Impact of Women in Public Office, Findings at a Glance', Center for the American Woman and Politics, Rutgers University, p. 4.
}

(C) Royal Economic Society 2000 
spread view that health issues, such as workers compensation, are relatively more important to women with political power. ${ }^{10}$

There are significant differences across the United States, both crosssectionally and over time, in the number of women serving in state legislatures. Fig. 2 presents the fraction of women in state lower houses from 1975 to 1993 for the 48 continental U.S. states. ${ }^{11}$ Some states witnessed a marked increase in the number of women serving over this period. California, Idaho, Kansas, and Washington, for example, saw large increases in women serving in their legislative lower houses. There are also notable differences between states in the mean number of women in the legislature over this period. Arkansas, Georgia, and Pennsylvania all witnessed changes in the number of women serving, but from very low bases.

Summary statistics for the composition of the states' legislatures are provided in Table 1, where data are also presented for the economic and demographic variables thought to influence policy choice and related economic outcomes of interest. The choice of the data period, 1975-88, reflects data availability.

The importance of women legislators in the setting of manual rates can be seen in the first four rows of Table 2. Holding constant the size of the state legislatures, an additional woman in the state's upper house or the state's lower house increases the manual rate for concrete construction workers by three-tenths of one percentage point. The number of women in the state lower

Table 1

Summary Measures for Political, Economic and Manual Rate Variables

\begin{tabular}{|c|c|c|c|c|}
\hline & Means & $\begin{array}{l}\text { Standard } \\
\text { deviation }\end{array}$ & Source & $\begin{array}{c}\text { Years } \\
\text { available }\end{array}$ \\
\hline $\begin{array}{l}\text { Manual rate concrete } \\
\text { construction workers }\end{array}$ & 8.23 & 4.60 & Burton and Schmidle & $1975-88$ \\
\hline $\begin{array}{l}\text { Employment, construction } \\
\text { workers }\end{array}$ & 88.88 & 91.14 & BLS & $1975-88$ \\
\hline $\begin{array}{l}\log \text { (average hourly } \\
\text { earnings) construction }\end{array}$ & 2.07 & 0.191 & CPS & $1979-88$ \\
\hline $\begin{array}{l}\text { State income per capita } \\
\text { (1982 dollars) }\end{array}$ & 11,252 & 1,812 & Statistical Abstract & $1975-88$ \\
\hline State population & $4,758,725$ & $4,869,385$ & Statistical Abstract & $1975-88$ \\
\hline Proportion elderly & 0.116 & 0.019 & Statistical Abstract & $1975-88$ \\
\hline Proportion black & 0.112 & 0.089 & Statistical Abstract & $1975-88$ \\
\hline $\begin{array}{l}\text { State total employment to } \\
\text { population ratio }\end{array}$ & 0.393 & 0.044 & BLS & $1975-88$ \\
\hline State unemployment rate & 6.88 & 2.26 & Statistical Abstract & $1975-88$ \\
\hline
\end{tabular}

10 See, for example, 'Women at Helm of New Hampshire Politics', The New York Times, A14, October 7, 1997 for discussion of 'the focus on "service" issues, like health care and education', anticipated of women with political power.

11 Data for these years were made available to us by the Center for the American Woman and Politics. One state, Nebraska, is unicameral. We assigned the number of women in the one Nebraska chamber to both women in the lower house and women in the upper house variables here.

(C) Royal Economic Society 2000 
Table 2

Determinants of Manual Rates 1975-88

Dep Var: Log (manual rate, concrete construction workers)*

(t-statistics in parentheses)

\begin{tabular}{|c|c|c|c|c|}
\hline $\log$ (state income per capita) & $\begin{array}{c}1.18 \\
(4.0)\end{array}$ & - & $\begin{array}{l}0.565 \\
(1.9)\end{array}$ & $\begin{array}{l}0.984 \\
(3.6)\end{array}$ \\
\hline Log(state population) & $\begin{array}{c}-0.885 \\
(2.2)\end{array}$ & - & $\begin{array}{c}-0.315 \\
(0.7)\end{array}$ & $\begin{array}{c}-0.383 \\
(0.9)\end{array}$ \\
\hline Proportion elderly & $\begin{array}{c}7.99 \\
(1.5)\end{array}$ & - & $\begin{array}{l}15.3 \\
(2.9)\end{array}$ & $\begin{array}{l}13.2 \\
(2.5)\end{array}$ \\
\hline Proportion black & $\begin{array}{r}-3.57 \\
(2.0)\end{array}$ & - & $\begin{array}{c}-3.35 \\
(2.0)\end{array}$ & $\begin{array}{c}-2.80 \\
(1.6)\end{array}$ \\
\hline F-test: economic variables ( $\mathrm{p}$-value) & $\begin{array}{l}8.46 \\
(0.0000)\end{array}$ & - & $\begin{array}{l}5.99 \\
(0.0001)\end{array}$ & $\begin{array}{l}7.29 \\
(0.0000)\end{array}$ \\
\hline Number of women in state upper house & - & $\begin{array}{c}-0.19 \\
(2.3)\end{array}$ & $\begin{array}{l}0.019 \\
(2.4)\end{array}$ & - \\
\hline Number of women in state lower house & - & $\begin{array}{l}0.024 \\
(7.1)\end{array}$ & $\begin{array}{l}0.024 \\
(6.1)\end{array}$ & - \\
\hline Number of members, state upper house & - & $\begin{array}{c}-0.034 \\
(2.9)\end{array}$ & $\begin{array}{c}-0.037 \\
(3.1)\end{array}$ & - \\
\hline Number of members, state lower house & - & $\begin{array}{c}-0.001 \\
(1.8)\end{array}$ & $\begin{array}{c}-0.001 \\
(0.6)\end{array}$ & - \\
\hline Fraction of women, state upper house & - & - & - & $\begin{array}{l}1.09 \\
(3.4)\end{array}$ \\
\hline Fraction of women, state lower house & - & - & - & $\begin{array}{c}2.55 \\
(5.5)\end{array}$ \\
\hline F-test: political variables (p-value) & - & $\begin{array}{l}14.62 \\
(0.0000)\end{array}$ & $\begin{array}{l}11.11 \\
(0.0000)\end{array}$ & $\begin{array}{l}21.39 \\
(0.0000)\end{array}$ \\
\hline
\end{tabular}

Notes:

* Huber standard errors used to calculate t-statistics. State and year indicator variables included in all regressions. Data are for the 48 continental U.S. states for the period 1975-88. Number of observations $=560$. Manual rates were unavailable for following states: California (data missing for 11 years), Deleware (11), Nevada (14), New Jersey (1), North Dakota (14), Mississippi (1), Ohio (11), Pennsylvania (10), Washington (14), West Virginia (11), and Wyoming (14).

and upper houses and the number of seats in these houses are highly significant determinants of the workers' compensation policy $($ F-statistic $=14.44$, pvalue $=0.0000)$.

Manual rates also respond to changes in state-level economic and demographic variables. Higher state income per capita, all else equal, appears to drive rates up. Elderly in a state's population also appear to drive rates higher. This parallels the findings of Poterba (1996) and bears witness to the political power of the elderly in shaping state policy. A larger proportion black in the state's population reduces the manual rate for concrete construction. We can think of this being correlated with taste differences that drive policy preferences. F-statistics following the economic variables suggest that the states' economic conditions play a significant role in the determining manual rates within the state.

Omitting economic and demographic control variables from incidence studies would be problematic. The effects of these variables that also determine outcomes of interest, if omitted from the equation determining outcomes of interest, would load onto the policy variable, biasing the estimated effect of the

(C) Royal Economic Society 2000 
policy. While we have a more or less standard list of such variables included in the regression, a concern remains that we have only identified some of the economic conditions that determine both policy choice and economic outcomes. Any others would be captured in the unobservables of the outcome equation and would lead to bias.

Overall, the evidence presented in Table 2 demonstrates that workers' compensation policies respond to state economic and political variables. The results of Table 2 are not only of independent interest in thinking about the political economy of workers' compensation, but suggest that incidence analysis should account for the purposeful action taken by state governments to bring policies into line with current economic and political conditions.

We now turn to models of policy incidence, where special attention will be given to the ability of different modelling strategies to cope with potential policy endogeneity. We begin with cross-state fixed effect models and show that estimates of a policy's effect are sensitive to the inclusion of state level variables that not only influence policy but also affect outcome variables directly. Direct inclusion of the policy change in an incidence equation may leave estimates open to omitted variable bias: any variable that potentially affects both the policy equation and the outcome equation that is inadvertently omitted from the outcome equation may bias estimates of the policy's effect. This is true whether the incidence estimation is performed on state-level outcome data or on micro-level outcome data. We then turn to discuss the relative merits of using similar workers in 'closely related' states as control groups.

\subsection{Fixed Effects Models}

We begin our investigation with a model of policy incidence that controls for state fixed effects and year effects. Such models constitute an advance over those that look at policy incidence in a cross-sectional framework. ${ }^{12}$ As discussed in the introduction, fixed effects models are now common in the literature on policy incidence. Most directly relevant to our study is the work of Gruber and Krueger (1991), who study the incidence of workers' compensation in this framework.

We look for effects of $P_{s t}$, the manual rate for concrete construction workers, on the employment and wages of construction workers. We obtain earnings measures from the outgoing rotation groups of the Current Population Survey (CPS) and aggregate them to the state level, using earnings weights, to get state level means. Employment data were obtained from the Geographic Profile of Employment and Unemployment.

Consider an outcome denoted by $Y_{s t}$. The canonical policy incidence equation is then

$$
Y_{s t}=\mathbf{X}_{s t} \mathbf{a}+b_{t}+c_{s}+\gamma P_{s t}+\left[u_{s t}+\mathbf{Z}_{s t} \boldsymbol{\delta}\right]
$$

\footnotetext{
12 The latter have been widely used, for example, to estimate the incidence of property taxes and the crowding out effects on private charity of public expenditures. Those studies that worried about policy endogeneity usually used an instrumental variables approach.
}

(C) Royal Economic Society 2000 
where $\mathbf{X}_{s t}$ is a row vector of characteristics of the relevant group of workers, averaged at the state level, $b_{t}$ is a year effect and $c_{s}$ is a state fixed effect. The bracketed variables $\mathbf{Z}_{s t}$ represent $\left[\mathbf{Q}_{s t} \mathbf{W}_{s t}\right]$, economic and political variables that were seen to influence $P_{s t}$ in the estimation results of equation (5). The variables $\mathbf{Z}_{s t}$ are, in general, absent from (6) and their effects are subsumed here in the error structure. Error component $u_{s t}$ represents those forces determining outcome $Y_{s t}$ that are unobservable and orthogonal to $\mathbf{Z}_{s t}$.

The key issue from a policy point of view concerns the sign, size and significance of the estimated parameter $\gamma$. To discuss the possible bias caused by policy endogeneity, we will use a tilde to denote variables net of the effects of $\mathbf{X}$ and year and state fixed effects. Thus $\tilde{Y}$ and $\tilde{P}$ denote those components of the outcome variable $Y$ and the policy variable $P$ that are orthogonal to group characteristics $\mathbf{X}$, year indicators, and state indicators. For simplicity in expressions to follow, denote collectively the economic and political variables that determine the policy equation, net of effects of $\mathbf{X}$, year and state indicators, as $\tilde{\mathbf{Z}}=[\tilde{\mathbf{Q}} \tilde{\mathbf{W}}]$, which is an $\left[n \times\left(k_{1}+k_{2}\right)\right]$ matrix of observations on economic and political variables. Denote the coefficients from (5) as $\boldsymbol{\rho}=[\boldsymbol{\phi} \zeta]$ which is a $\left[\left(k_{1}+k_{2}\right) \times 1\right]$ column vector of coefficients in the policy determination equation. The equation describing the policy variable can then be written

$$
\tilde{\mathbf{P}}=\tilde{\mathbf{Z}} \rho+\boldsymbol{v}
$$

The OLS estimate of $\gamma$ from (6), with $\mathbf{Z}$ omitted from the set of control variables, can be written

$$
\hat{\gamma}=\left(\tilde{\mathbf{P}}^{\prime} \tilde{\mathbf{P}}\right)^{-1} \tilde{\mathbf{P}}^{\prime} \tilde{\mathbf{Y}}
$$

Substituting for $\tilde{\mathbf{Y}}$ from (6) yields

$$
\hat{\gamma}=\gamma+\left(\tilde{\mathbf{P}}^{\prime} \tilde{\mathbf{P}}\right)^{-1} \tilde{\mathbf{P}}^{\prime} \mathbf{u}+\left(\tilde{\mathbf{P}}^{\prime} \tilde{\mathbf{P}}\right)^{-1} \tilde{\mathbf{P}}^{\prime} \tilde{\mathbf{Z}} \boldsymbol{\delta}
$$

The probability limit of $\hat{\gamma}$ is

$$
\operatorname{plim} \hat{\gamma}=\gamma+\operatorname{plim}\left[\left(\frac{\tilde{\mathbf{P}}^{\prime} \tilde{\mathbf{P}}}{n}\right)^{-1}\left(\frac{\boldsymbol{v}^{\prime} \mathbf{u}}{n}\right)\right]+\operatorname{plim}\left[\left(\frac{\tilde{\mathbf{P}}^{\prime} \tilde{\mathbf{P}}}{n}\right)^{-1} \boldsymbol{\rho}^{\prime}\left(\frac{\tilde{\mathbf{Z}}^{\prime} \tilde{\mathbf{Z}}}{n}\right) \boldsymbol{\delta}\right]
$$

where substitution has been made for $\tilde{\mathbf{P}}$ from (7) and terms with plims equal to zero have been dropped.

It is clear from (10) that there are potentially two, related, sources of bias in cross-state fixed effect estimation. The second bracketed term of (10) represents omitted variable bias caused by observable variables that determine policy and that have independent influence on the outcome of interest. The size of this effect depends upon the magnitudes of $\boldsymbol{\delta}$ and $\rho$. The importance of this omission is an empirical matter.

A second potential source of bias is due to the presence of unobservable variables that may determine both the policy and the outcome of interest. It is possible, for example, that some unobservable measure of pessimism about the state's potential for economic growth may influence both the generosity of 
state workers' compensation benefits and the employment of workers in a particular sector. This potential bias, represented by the first bracketed term in (10), is more difficult to protect against in cross-state fixed effect estimation. We will discuss this in more detail below.

We illustrate in Tables 3 and 4 the impact of exclusion and inclusion of different variables $[\mathbf{Q} \mathbf{W}]$ for outcomes thought to be influenced by workers' compensation benefits. We estimate the effect of changes in log manual rate on the log of employment in construction (Table 3) and on log average hourly earnings of construction workers (Table 4). In Table 3, moving from left to right in the table, we include different controls for the types of variables found to influence manual rates directly in Table 2. Note that we always include year indicators.

It is interesting to focus on the first row, which reports the estimated effect of changes in the log manual rate, $\gamma$ above. The results vary dramatically with the controls chosen: without control for state fixed effects, the manual rate appears to have a positive and significant effect on employment (column 1). With control for state fixed effects, in the absence of time-varying state level variables, manual rates appear to have a very small, negative effect on employment that is insignificantly different from zero (column 2). The addition of log state income per capita to the controls leads to a large, negative and significant effect of manual rates on employment (column 3). All of the timevarying state-level controls - state income per capita, log state population, proportion elderly, proportion black, the employment-to-population ratio for the state, and the state unemployment rate - have significant effects on employment in construction. ${ }^{13}$ We have seen in Table 2 that these variables also have independent effects on the manual rates. When time-varying state level economic variables are omitted from these outcome equations, their effect is added onto that estimated for workers' compensation benefits, as in the second bracketed term of (10). The inclusion or exclusion of variables that determine both policy and behavioral outcomes dramatically alter the estimated impact of the policy change. In light of our estimates of (5), none of the findings in Tables 3 and 4 are very surprising. However, they are a reminder that inadequate controls for time-varying state level variables may bias estimates of policy incidence identified from state-level policy variation. The last columns in Tables 3 and 4 suggest that increases in manual rates lead to significant reductions in the employment and earnings of construction workers. However, it is not clear that simply including state economic variables leads to an unbiased estimate of $\gamma$. There is still potential for bias caused by policy endogeneity, as presented in the first bracketed term of (10) above.

\footnotetext{
13 In Table 3, we instrument the employment-to-population ratio and the state unemployment rates with their lags, because these are jointly determined with employment in construction. In Table 4, we instrument the $\log$ (state income per capita) with one lag in $\log$ (state income per capita), because state income per capita is jointly determined with average hourly earnings in construction. The results presented in Tables 3 and 4 do not change with these variables are not instrumented. (See notes to the tables for more details.)
}

(C) Royal Economic Society 2000 
Determinants of Employment in Construction

Dependent Variable: Log (number of workers employed in contruction) 1975-88*

(t-statistics in parentheses)

\begin{tabular}{|c|c|c|c|c|c|c|c|}
\hline & OLS & OLS & OLS & OLS & OLS & OLS & OLS \\
\hline Log (manual rate) concrete construction workers & $\begin{array}{l}0.217 \\
(2.9)\end{array}$ & $\begin{array}{c}-0.012 \\
(0.3)\end{array}$ & $\begin{array}{c}-0.076 \\
(3.2)\end{array}$ & $\begin{array}{l}0.017 \\
(0.5)\end{array}$ & $\begin{array}{c}-0.003 \\
(0.1)\end{array}$ & $\begin{array}{c}-0.009 \\
(0.2)\end{array}$ & $\begin{array}{c}-0.048 \\
(3.7)\end{array}$ \\
\hline Log (state income per capita) & - & - & $\begin{array}{r}2.90 \\
(23.7)\end{array}$ & - & - & - & $\begin{array}{l}0.378 \\
(1.8)\end{array}$ \\
\hline Log (state population) & - & - & - & $\begin{array}{c}1.26 \\
(6.6)\end{array}$ & - & - & $\begin{array}{r}1.43 \\
(13.0)\end{array}$ \\
\hline Proportion elderly & - & - & - & - & $\begin{array}{r}-8.12 \\
(2.7)\end{array}$ & - & $\begin{array}{r}-2.37 \\
(1.7)\end{array}$ \\
\hline Proportion black & - & - & - & - & - & $\begin{array}{c}4.55 \\
(3.9)\end{array}$ & $\begin{array}{c}2.04 \\
(4.2)\end{array}$ \\
\hline State total employment to population ratio $\dagger$ & - & - & - & - & - & - & $\begin{array}{c}5.78 \\
(7.5)\end{array}$ \\
\hline State unemployment rate $\uparrow$ & - & - & - & - & - & - & $\begin{array}{c}-0.037 \\
(5.8)\end{array}$ \\
\hline State indicators? & No & Yes & Yes & Yes & Yes & Yes & Yes \\
\hline Year indicators? & Yes & Yes & Yes & Yes & Yes & Yes & Yes \\
\hline
\end{tabular}

\section{Notes:}

* Huber standard errors used to calculate t-statistics. Number of observations $=553$. Manual rates were unavailable for some years in the following states: California (data missing for 11 years), Deleware (11), Nevada (14), New Jersey (1), North Dakota (14), Mississippi (1), Ohio (11), Pennsylvania (10), Washington (14), West Virginia (11), and Wyoming (14). (This is 14 years of data for all other continental US states, with the exception of Connecticut from 1975-81, for which employment data were not available).

$\dagger$ Employment/Population ratio and unemployment rate were instrumented using one lag each in the employment/population ratio and the state unemployment rate, because these may be simultaneously determined with employment in construction. (F-test of these lags in the Employment/Population equation, controlling for $\log$ (state income per capita), $\log$ (state population), proportion elderly and proportion black, and state and year effects, was 202.70 . F-test of these lags in the unemployment rate equation ( $\mathrm{nm}$ with same right side variables) was 147.35.) Results in column 7 are robust to running these models without instrumenting for

potential endogeneity of employment/population and unemployment rate. 
Table 4

Determinants of Average Hourly Earnings in Construction

Dependent Variable: Log (average hourly earnings in construction) 1979-88*

(t-statistics in parentheses)

\begin{tabular}{|c|c|c|c|c|c|c|c|}
\hline & OLS & OLS & OLS & OLS & OLS & OLS & OLS \\
\hline Log (manual rate) concrete construction workers & $\begin{array}{l}0.027 \\
(2.6)\end{array}$ & $\begin{array}{c}-0.009 \\
(0.6)\end{array}$ & $\begin{array}{c}-0.021 \\
(1.6)\end{array}$ & $\begin{array}{c}-0.006 \\
(0.4)\end{array}$ & $\begin{array}{c}-0.019 \\
(1.3)\end{array}$ & $\begin{array}{c}-0.014 \\
(1.0)\end{array}$ & $\begin{array}{c}-0.022 \\
(1.7)\end{array}$ \\
\hline $\log ($ state income per capita) $\dagger$ & - & - & $\begin{array}{c}0.793 \\
(11.5)\end{array}$ & - & - & - & $\begin{array}{r}1.31 \\
(6.4)\end{array}$ \\
\hline Log (state population) & - & - & - & - & - & - & $\begin{array}{c}-0.245 \\
(1.8)\end{array}$ \\
\hline Proportion elderly & - & - & - & - & - & - & $\begin{array}{r}-1.52 \\
(1.0)\end{array}$ \\
\hline Proportion black & - & - & - & $\begin{array}{l}1.06 \\
(2.7)\end{array}$ & - & - & $\begin{array}{c}-0.241 \\
(0.6)\end{array}$ \\
\hline State total employment to population ratio & - & - & - & - & $\begin{array}{c}1.94 \\
(9.7)\end{array}$ & - & $\begin{array}{c}-2.02 \\
(3.0)\end{array}$ \\
\hline State unemployment rate & - & - & - & - & - & $\begin{array}{c}-0.017 \\
(6.2)\end{array}$ & $\begin{array}{c}-0.002 \\
(0.5)\end{array}$ \\
\hline Worker characteristics? & Yes & Yes & Yes & Yes & Yes & Yes & Yes \\
\hline State indicators? & No & Yes & Yes & Yes & Yes & Yes & Yes \\
\hline Year indicators? & Yes & Yes & Yes & Yes & Yes & Yes & Yes \\
\hline
\end{tabular}

Notes:

* Huber standard errors used to calculate t-statistics. Number of observations $=406$. Manual rates were unavailable for some years in the following states: California (data missing for 7 years), Deleware (7), Nevada (10), North Dakota (10), Ohio (7), Pennsylvania (6), Washington (10), West Virginia (7), and Wyoming (10). (This is 10 years of data for all other continental US states).

$\dagger$ Log state income per capita was instrumented using one lag in log state income per capita, because this is simultaneously determined with log average hourly earnings in construction. (t-test of this lag in the $\log$ (state income per capita) equation, controlling for log(state population), proportion elderly, proportion black, employment/population ratio, state unemployment rate, and state and year effects, was 15.7. Results in column 7 are robust to running this model without instrumenting for potential endogeneity of $\log$ (state income per capita). 


\subsection{Selecting Control States}

One way of dealing with these concerns is to try to identify the policy effect by selecting a control group of workers in the same industry or occupation in states where the policy variable did not change, among states thought to be 'similar' to that whose policy has changed. For the case of workers' compensation, we can see in Fig. 1 that Colorado (CO), Montana (MT), and New Hampshire $(\mathrm{NH})$ all experienced large increases in their concrete construction worker manual rates between 1981 and 1988. In that time period, the manual rate increased in Colorado by $9.2 \%$ of payroll, in Montana by $24.3 \%$ of payroll, and in New Hampshire by $14.9 \%$ of payroll. Several other states had no significant change in their manual rates during this period. These include Minnesota $(\mathrm{MN})$, which saw a $0.4 \%$ increase, and Oregon and Kentucky, neither of which raised their rates during this period. We will refer to the states that have seen their policies change as the 'treatment' group and to those that have not as the 'control' group. We will label the former as state(s) 1 and the latter as state(s) 2. We then take two years (1981 and 1988), one before and one after the policy change occurred.

Generally, policy incidence in cross-state difference-in-difference estimation is performed by pooling observations from groups 1 and 2 and then either calculating the simple difference in outcomes across states across time $\left(\Delta Y_{1}-\Delta Y_{2}\right)$, where $\Delta$ denotes a time difference, or running regressions of the form

$$
Y_{i s t}=\gamma \omega_{i} \tau_{t}+b \tau_{\tau}+c \omega_{i}+a_{1} X_{i s t} \omega_{i}+a_{2} X_{i s t}\left(1-\omega_{i}\right)+e_{i s t}
$$

where $\omega_{i}=1$ if $i$ is the treatment state, and zero otherwise. In this equation, $\tau_{\tau}$ is an indicator for observations after the change in policy has taken effect, so that $\omega_{i} \tau_{t}-$ our proxy for $\omega_{i} P_{s t}-$ is an indicator that the observation comes from the treatment group after the treatment has occurred. The treatment and control group's observable characteristics are allowed to have different effects on the outcome (i.e., $a_{1}$ may differ from $a_{2}$ ). The estimate of policy incidence on the treatment group, $\gamma$, is estimated as the post-treatment change in outcome for the treatment group, after controlling for the mean change in outcomes observed pre- and post-treatment $(b)$ and for the mean difference in outcomes between the treatment and control group $(c)$. The estimate of policy incidence on the treatment group, $\gamma$, is estimated as the post-treatment change in outcome for the treatment group, after controlling for the mean change in outcomes observed pre- and post-treatment (b) and for the mean differences in outcomes between the treatment and control group $(c)$.

There are two identification assumptions maintained in difference-in-difference estimation. The first is that, apart from the control variables included $(\mathbf{X})$, there are no other forces affecting the treatment and control groups differentially pre- and post-treatment. In addition, the composition of the treatment group and control group must remain stable over the period. These assumptions-that the time effects must be identical between the treatment group and control group, and that the groups' compositions must remain the same-are discussed in detail in Blundell and MaCurdy (forthcoming). These 
authors emphasise the latter point, that policies often change who works and who does not in a systematic fashion.

Again our estimate of (5) can help to inform us of necessary conditions for the estimation of $\gamma$ to be unbiased. For cross-state difference in difference estimation using (11) to provide an unbiased estimate of $\gamma$, it must be the case that either time-varying state level variables did not change between the preand post-treatment period or that they changed in an identical manner in the control and treatment states. Furthermore, there must be no time-varying state level unobservable variables determining outcomes that vary, pre- and posttreatment, between the states.

Table 5 demonstrates that the estimated incidence of a policy change can vary greatly with the choice of states designated as 'control' states. States that have not experienced a policy change need not have had similar experiences in terms of their relevant economic conditions. Table 5 presents the change in manual rates for potential 'treatment' and 'control' states, together with information on the growth of wages and employment for construction workers, changes in state income per capita, and changes in unemployment in these states between 1981 and 1988 .

The issues can be seen by comparing wage growth in one treatment state, Colorado, with that in a control, Minnesota, and to see how different the comparison is when a different treatment state, New Hampshire is chosen. Comparison of Colorado and Minnesota suggests that construction workers' wages suffered as a result of the increase in workers' compensation benefits. Wages of construction workers grew only 9\% between 1981 and 1988 in Colorado, but grew $28 \%$ in Minnesota, which observed a much lower increase

Table 5

Difference in Difference Estimation 1981-88

Dependent Variables: Changes in log (average hourly earnings, construction) and changes in employment in construction

\begin{tabular}{|c|c|c|c|c|c|c|}
\hline & \multicolumn{3}{|c|}{ Treatment States } & \multirow{2}{*}{\multicolumn{3}{|c|}{ Control States }} \\
\hline & \multirow[b]{2}{*}{ Colorado } & \multirow[b]{2}{*}{ Montana } & \multirow{2}{*}{$\begin{array}{c}\text { New } \\
\text { Hampshire }\end{array}$} & & & \\
\hline & & & & Kentucky & Minnesota & Oregon \\
\hline $\begin{array}{l}\text { Change in log (manual rate) } \\
\text { concrete construction } \\
\text { workers }\end{array}$ & 9.22 & 24.3 & 14.9 & 0 & 0.400 & 0 \\
\hline $\begin{array}{l}\text { Change in employment, } \\
\text { construction }\end{array}$ & -17.1 & -4.3 & 15.6 & 10.1 & 10.1 & 2.40 \\
\hline $\begin{array}{l}\text { Change in log (average } \\
\text { hourly earnings) }\end{array}$ & 0.092 & 0.195 & 0.367 & 0.114 & 0.249 & 0.073 \\
\hline $\begin{array}{l}\text { Change in state } \\
\text { unemplovment rate }\end{array}$ & 0.900 & -0.100 & -2.6 & -0.500 & -1.5 & -4.10 \\
\hline $\begin{array}{l}\text { Change in state income } \\
\text { per capita (in } 1982 \\
\text { dollars) }\end{array}$ & 1,523 & 505 & 5,242 & 1,520 & 2,169 & 1,517 \\
\hline
\end{tabular}

(C) Royal Economic Society 2000 
in manual rates. However, this ignores the fact that Colorado had an increase in unemployment during this period, while unemployment fell in Minnesota during this same period. (State income per capita grew more slowly in Colorado over this period as well.) If, instead, New Hampshire is compared with Minnesota, it appears that the change in workers' compensation benefits in New Hampshire had little effect on the wages of construction workers. But unemployment fell dramatically in New Hampshire (and state income per capita surged) over this period of time.

This highlights two general points. First, using a difference-in-difference estimator across states may understate the variance in incidence estimates because it does not reflect true sampling variability of outcomes in potential control states. Second, it may yield a biased estimate of policy incidence, because the economic conditions that brought about the policy change may have independent effects on the outcome variable of interest. This is, of course, just another way of seeing our main point about policy endogeneity and its effect on incidence analysis. There are good reasons, in light of Table 2 , to suspect that the same economic conditions were not present in the 'control' states, because their policies did not change.

Some researchers have combined comparison of within-state outcomes for 'control' and 'experimental' groups with comparison across an 'experimental' state and set of 'control' states. Here, researchers first obtain difference-indifference estimates between control and experimental states for control groups and, separately, for the group of interest. They then take this difference across the control and experimental groups. It is not clear a priori whether the estimate of $\gamma$ from this difference-in-difference-in-difference (DDD) estimator is any less or more biased than that obtained from using the difference-indifference techniques discussed above. This will depend both upon the extent to which $[\mathbf{Q} \mathbf{W}]$ vary between the control and treatment states and the extent to which there are differences in the coefficients for the control and treatment groups.

In many DDD analyses, workers in one part of the earnings distribution are used as controls for workers in another part of the distribution, who are directly affected by a policy change. Low wage workers have been used as controls for high wage workers in some studies, when a change in a benefit cap has altered the benefit payable to high wage workers only. We know from recent research, however, that the wages and employment of less skilled workers respond differently to changes in economic conditions than do the wages and employment of more skilled workers. (See for example Farber (1993), Figs. 2 and 3.) Gruber (1994) compares the wages of women of child bearing age in the 'experimental' states of New York and New Jersey with those in the 'control' states of North Carolina, Connecticut, and Massachusetts, in order to observe the impact of mandatory maternity benefits, and takes the difference between outcomes for women of child bearing age and those of older workers. If older workers are better protected over the business cycle than are younger workers, then the older workers are not an adequate control group for younger workers.

(C) Royal Economic Society 2000 
The analysis above suggests that 'control' groups must meet certain conditions to yield unbiased estimates of the impact of policies using differences-indifferences estimation. ${ }^{14}$ Moreover, Table 2 gives us a sign post in searching for such 'controls'. More generally, cross-state fixed effect estimation and difference-in-difference estimation can be interpreted as instrumental variable estimation. Just as it is incumbent upon researchers using standard instrumental variables to take a hard look at their instrument list, it is necessary for researchers using difference-in-difference techniques to justify their selection of 'controls'. Indeed, the criteria that must be met in the two types of estimation are different sides of the same coin. ${ }^{15}$

\section{On the Use of Political and Economic Variables as Instruments}

Finding some variables that have an independent effect on policy and not on the outcome of interest would enable the researcher to use a more standard instrumental variable procedure to rid the analysis of potential endogeneity bias. It is the main alternative candidate to searching for a control group when confronted with an endogeneity problem. This section looks at this possibility using our example of workers' compensation benefits. One general idea that has heretofore received relatively little attention is using political variables as instruments. We show that this idea has some merit, although it is not a panacea for dealing with endogeneity problems.

One immediate attraction of IV estimation is that the researcher must first make plain the independent source of policy variation. As was seen in Table 2, workers' compensation benefits respond to changes in a state's economic, demographic, and political conditions. IV estimation allows us to test whether one (or many) such sources of policy variation are appropriate for use in identifying the effect of the policy change. Over-identification tests can be used to highlight sources of policy variation that are inappropriate because they have independent effects on the outcomes of interest, a concern raised with both cross-state fixed effect and difference-in-difference estimation above. A second merit of the IV approach is that we can control simultaneously for other determinants of the outcome under study. This may include variables that simultaneously determine policy choice and outcome variables.

However, there are drawbacks from this method too. Chief among them is the need to find convincing instruments. It is possible that this problem is diminished here, for state policy changes, because political variables provide a rich, relatively unexplored, set of candidates for instruments.

\footnotetext{
14 For a discussion of this issue in a different context, see Blundell et al. (1998).

15 One method that we have not discussed so far, but which is affected by policy endogeneity, is the use of state laws as instruments in incidence analysis. For example, Danziger et al. (1982) model the decision made by women to head their own household as a function of the women's outside opportunities, which are modelled as a function of state maximum AFDC benefits. Gruber (1997) estimates the effect of unemployment insurance (UI) on the food consumption of unemployed workers by instumenting workers' unemployment insurance on state UI laws. State laws are valid instruments in such cases only if the determinants of the law changes are uncorrelated with that portion of the explanatory variable that is thought to be purged by instrumental variable estimation.
}

(C) Royal Economic Society 2000 
Table 6 explores instrumentation of workers' compensation benefits. Here we provide IV estimates of the impact of changes in log manual rates on the employment and earnings of construction workers. In the first stage, we instrument $\log$ (manual rates) on the fraction of women in state upper and lower houses (as in column 4 of Table 2). These two variables are highly

\section{Table 6}

\section{Instrumental Variable Estimation: Employment and Earnings Construction}

Dependent Variable: Log (average hourly earnings, construction) 1979-88*

(t-statistics in parentheses)

\begin{tabular}{|c|c|c|c|c|}
\hline & \multicolumn{2}{|c|}{$\log ($ employment $)$} & \multicolumn{2}{|c|}{ Log(average hourly earnings) } \\
\hline & OLS & TSLS & OLS & TSLS \\
\hline \multirow{2}{*}{$\begin{array}{l}\log (\text { manual rate }) \text { concrete } \\
\text { construction workers }\end{array}$} & -0.048 & -0.143 & -0.022 & 0.003 \\
\hline & $(3.7)$ & $(3.1)$ & $(1.7)$ & $(0.1)$ \\
\hline \multirow[t]{2}{*}{ Log (state income per capita) } & 0.378 & 0.523 & 1.31 & 1.33 \\
\hline & $(1.8)$ & $(2.3)$ & $(6.4)$ & $(6.4)$ \\
\hline \multirow[t]{2}{*}{ Log (state population) } & 1.43 & 1.37 & -0.245 & -0.229 \\
\hline & $(13.0)$ & $(11.6)$ & $(1.8)$ & $(1.7)$ \\
\hline \multirow[t]{2}{*}{ Proportion elderly } & -2.37 & -1.61 & -1.52 & -1.49 \\
\hline & $(1.7)$ & $(1.0)$ & $(1.0)$ & $(1.0)$ \\
\hline \multirow[t]{2}{*}{ Proportion black } & 2.04 & 1.74 & -0.241 & -0.154 \\
\hline & $(4.2)$ & $(3.0)$ & $(0.6)$ & $(0.4)$ \\
\hline \multirow{2}{*}{$\begin{array}{l}\text { State total employment to } \\
\text { population ratio } \dagger\end{array}$} & 5.78 & 5.76 & -2.02 & -2.13 \\
\hline & $(7.5)$ & $(7.1)$ & $(3.0)$ & $(3.1)$ \\
\hline \multirow[t]{2}{*}{ State unemployment rate $\uparrow$} & -0.037 & -0.034 & -0.002 & -0.002 \\
\hline & $(5.8)$ & $(5.2)$ & $(0.5)$ & $(0.5)$ \\
\hline Worker characteristics? & N.A. & N.A. & Yes & Yes \\
\hline \multirow[t]{2}{*}{ Over-identification test } & - & 1.23 & & 0.96 \\
\hline & & $(0.2936)$ & & $(0.3825)$ \\
\hline
\end{tabular}

Notes:

* Huber standard errors used to calculate t-statistics. Number of observations in columns 1 and 2 $=553$, and in columns 3 and $4=406$. State and year indicators included in all regressions. Worker characteristics included in the $\log$ (average hourly earnings) equation, but were unavailable for the employment equations.

$\uparrow$ In columns 1 and 2: Employment/Population ratio and unemployment rate were instrumented using one lag each in the employment/population ratio and the state unemployment rate, because these may be simultaneously determined with employment in construction. (F-test of these lags in the Employment/Population equation, controling for log (state income per capita), log(state population), proportion elderly and proportion black, and state and year effects, was 202.70. F-test of these lags in the unemployment rate equation (run with same right side variables) was 147.35.) Results in column 1 are robust to running these models without instrumenting for potential endogeneity of employment/ population and unemployment rate.

: In columns 3 and 4: Log state income per capita was instrumented using one lag in log state income per capita, because this is simultaneously determined with log average hourly earnings in construction. (t-test of this lag in the $\log$ (state income per capita) equation, controlling for $\log$ (state population), proportion elderly, proportion black, employment/population ratio, state unemployment rate, and state and year effects, was 15.7. Results in column 3 are robust to running this model without instrumenting for potential endogeneity of $\log$ (state income per capita).

$\$$ In columns 2 and 4, the $\log$ (manual rate) is instrumented on fraction of women in the state upper house and fraction of women in the state lower house. (See Table 2 for details on the first stage regression.) Over-identification test in column 2 is an F-test of the joint significance of these instruments in a regression of $\left[\log (\right.$ employment $)-b_{\mathrm{TSLS}} \times \log ($ manual rate $\left.)\right]$ on all right side variables and instruments, and in column 4 is an F-test of the joint significance of these instruments in a regression of $\left[\log (\right.$ average hourly earnings $)-b_{\mathrm{TSLS}} \times \log ($ manual rate $\left.)\right]$ on all right side variables and instruments.

(C) Royal Economic Society 2000 
significant predictors of the manual rates. An F-test of their joint significance takes the value 21.39. We use the predicted value from this first stage in a second stage regression of employment (column 2) and log average hourly earnings (column 4) of construction workers.

The cross-state fixed effect results and the TSLS results provide a consistent picture of the impact of workers' compensation on employment. The results suggest that increases in workers' compensation benefits have a negative and significant effect on the employment of construction workers in the state. The last row of the table provides over-identification tests of the orthogonality of residuals and instruments. ${ }^{16}$ It appears that these political variables do not have independent effects on the employment of construction workers.

In contrast, the fixed-effect results and the TSLS results lead to differing conclusions on the impact of workers' compensation benefits on earnings. Results in column 4 suggest that workers' compensation benefits have no significant effect on earnings. The coefficient is small $(0.003)$ with a standard error ten times that size. The over-identification test suggests that the instruments do not belong in the second stage regression of $\log$ (average hourly earnings) on $\log$ (manual rates).

Many of the studies that have looked at the impact of workers' compensation benefits on wages are summarised in Moore and Viscusi (1990). Most point towards a negative effect on wages from increasing workers' benefits. Recent work by Gruber and Krueger (1991) and Fishback and Kantor (1995) has strengthened this to claim not just a negative effect, but a one-for-one effect on wages. Indeed, this one-for-one offset view might now be called the "new conventional wisdom" and has been influential in policy discussion on number of issues. Less has been written about employment effect. However, it is worth bearing in mind that an implication of the one-for-one wage effect is that workers pay for the increased benefit so that effects on employment should be negligible.

Neither our OLS or TSLS results are consistent with the new conventional wisdom that increases in benefits induce one-for-one shifting. Instead, our results are more supportive of the view that workers do not value these benefits very much, so that wages remain unchanged, employment costs rise and labour demand is reduced. However, this claim does not hinge critically on our use of women's participation as an instrument. It seems much more likely that our expanded data period compared to the study of Gruber and Krueger (1991) and use of a different set of controls explains our failure to find an impact on wages. ${ }^{17}$ We are not aware of previous estimates of the employment effects of policy that can be compared with our estimates. Our TSLS results suggest that

\footnotetext{
16 This is an F-test for the presence of the instrument list in a regression of $Y-\hat{\gamma} P$ on the variables included in the second stage, corrected for degrees of freedom.

17 Looked at collectively, our results on wages are not actually inconsistent with the general thrust of their results. Using four years of data, Gruber and Krueger (1991) and not controlling for other aspects of states' economic conditions, they find a coefficient of -0.517 (s.e. 0.327 ) for carpenters, -0.651 (s.e. 0.839 ) for gas station workers, -0.119 (s.e. 0.577) for hospital workers, 1.729 (s.e. 1.050) for plumbers, and -0.966 (s.e. 0.331 ) for truck drivers.
}

(C) Royal Economic Society 2000 
the employment effects from OLS estimates may underestimate the impact of increased manual rates on employment.

Our attempt to use political variables as instruments is broadly encouraging. They also leave the reader in no doubt where the source of policy variation is coming from in estimating incidence. In general, however, we do not believe that the impact of political, economic or demographic variables on outcomes of interest can be known a priori. This must be handled on a case-by-case basis.

\section{Concluding Remarks}

The purpose of this paper has been to explore the use of different methods for estimating policy incidence when there is a concern about policy endogeneity. For the sake of concreteness, we have explored in detail the example of workers' compensation benefits. However, we hope that some of the discussion is of wider applicability. Given that cross-state variation in policy is such a rich potential source for identifying the effects of policy, the ideas discussed here should have broader significance.

Taking endogeneity seriously first raises the issue of identification and throws into question some cross-state fixed effect estimates. Are there independent sources of policy variation that allow us to identify the incidence at all? Our latter explorations using instrumental variables make us sanguine about this. Moreover, political variables are a potentially rich and relatively unexplored source of instruments.

Identification is not the only issue, it is only a necessary condition for being able to study the effects of policy. Researchers must also be able to control other forces at work driving outcomes. The use of control groups has become a popular method of attempting to control for changes in other variables that are at work on the group in question. Above, we derived the conditions for unbiased estimation of policy effects when policy is endogenous. Our investigation showed that these conditions are quite demanding. It is difficult in some exercises to find either within-state and/or cross-state groups for whom the effect of economic forces are the same as for the group of interest. Since the quality of a difference-in-differences estimation is crucially dependent on the quality of the control group chosen, we think greater attention should be paid to this in future analysis in this vein.

As a practical matter we think that the results in Table 2, where we looked at the impact of state political and economic characteristics on policy choice, are key. Studying what drives policy is a central concern of public finance and political economy. However, it has two further merits. Estimation of policy equations may inform the selection of control groups and provides a way of identifying useful instruments. These latter findings are of potentially wide applicability. We have also reasserted the merits of instrumental variable estimation, not as a panacea, but as a mechanism both for identifying sources of independent policy variation and of controlling for other determinants of outcomes and policies.

We are not arguing here that our procedure will always work. That must be

(C) Royal Economic Society 2000 
assessed on a case-by-case basis. Nonetheless, for an array of health and family issues, where the influence of women in the political process is argued to be most felt, it would appear to be a promising method which deserves further investigation. ${ }^{18}$ There is little doubt that policy choice is purposeful action and can rarely be treated as experimental data. The real issue is how to deal with this. This paper suggests that an agenda that looks for well-defined and measurable features of the policy process to help deal with such problems.

\section{Princeton University and NBER}

\section{References}

Anderson, Patricia M. and Meyer, Bruce D. (1997). 'The effects of firm specific taxes and government mandates with an application to the U.S. unemployment insurance program', Journal of Public Economics vol. 65(2), pp. 119-45.

Berkowitz E.D. and Berkowitz, M. (1985). 'Challenges to workers' compensation: an historical analysis', in (John D. Worrall and David Appel, eds.), Workers' Compensation Benefits: Adequacy, Equity and Efficiency, Ithaca, New York: Cornell University, New York State School of Industrial and Labour Relation.

Besley, Timothy J. and Case, Anne C. (1995). 'Incumbent behavior: vote seeking, tax setting and yardstick competition', American Economic Review vol. 85(1), pp. 25-45.

Besley, Timothy and Case, Anne (1995). 'Does political accountability affect economic policy choices? Evidence from gubernatorial term limits', Quarterly Journal of Economics vol. 110(3), pp. 769-98.

Blank, Rebecca M., George, Christine C. and London, Rebecca A. (1996). 'State abortion rates: the impact of policies, providers, politics, demographics, and economic environment', Journal of Health Economics vol. 15(5), pp. 513-53.

Blundell, Richard, Duncan, Alan and Meghir, Costas (1998). 'Estimating labor supply responses using tax reforms,' Econometrica, vol. 66(4), pp. 827-62.

Blundell, Richard and MaCurdy, Thomas (forthcoming) 'Chapter 27: Labor supply: a review of alternative approaches', in (Orley Ashenfelter and David Card, eds.), Handbook of Labor Economics, Amsterdam: North-Holland.

Card, David (1992). 'Do minimum wages reduce employment? A case study of California, 1987-89', Industrial and Labor Relations Review vol. 46(1), pp. 38-54.

The Center for the American Woman and Politics, Women in State Legislatures, Fact Sheets, Rutgers University, New Brunswick NJ, (various years).

Chelius, James R. (1977). Workplace Safety and Health: The Role of Workers' Compensation. Washington. D.C.: American Enterprise Institute for Public Policy Research.

Chiappori, Pierre-Andre, Durand, Franck and Geoffard, Pierre-Yves (1998). 'Moral hazard and the demand for physician services: first lessons from a French natural experiment', European Economic Review vol. 42, pp. 499-511.

Danziger, Sheldon, Jakubson, George, Schwartz, Saul and Smolensky, Eugene (1982). 'Work and welfare as determinants of female poverty and household headship', Quarterly Journal of Economics vol. $97(3)$, pp. 519-34.

Danzon, P.M. (1992). 'The determination of workers' compensation benefit levels', in (David Durbin and Philip S. Borba, eds.), Workers' Compensation Insurance: Claim Costs, Prices and Regulation, Norwell, MA: Kluwer Academic Publishers.

Diamond, Peter, (1977). 'Insurance theoretic aspects of workers' compensation', in (Alan S. Blinder and Philip Friedman, eds), Natural Resources, Uncertainty and General Equilibrium Systems: Essays in Memory of Rafael Lusky, New York: Academic Press.

Farber, Henry S. (1993). 'The incidence and costs of job loss: 1982-1992' Brookings Papers on Economic Activity: Microeconomics, pp. 77-132.

Fishback, Price V. and Kantor, Shawn Everett (1995), 'Did workers pay for the passage of workers' compensation laws?' Quarterly Journal of Economics, vol. 105(3), pp. 713-42.

Gruber, Jonathan, (1994). 'The incidence of mandated maternity benefits', American Economic Review, vol. $84(3)$, pp. $622-41$.

18 Its usefulness need not be confined to US political structure and may even extend to developing countries. For example, Pande (1999) explores an Indian context and whether reserving seats for disadvantaged castes has enhanced programmes targeted to these groups.

(C) Royal Economic Society 2000 
Gruber, Jonathan, (1997). 'The consumption smoothing benefits of unemployment insurance', American Economic Review vol. 87(1), pp. 192-205.

Gruber, Jonathan and Krueger, Alan (1991). 'The incidence of mandated employer-provided insurance: lessons from workers' compensation insurance', in (David Bradford, ed.), Tax Policy and the Economy, Cambridge MA: MIT Press.

Gruber, Jonathan and Madrian, Brigitte C. (1997). 'Employment separation and health insurance coverage', Journal of Public Economics vol. 66, pp. 349-82.

Meyer, Bruce D., (1995). 'Natural and quasi-experiments in economics', Journal of Business and Economic Statistics vol. 13(2), pp. 151-61.

Meyer, Bruce D., Viscusi, W. Kip and Durbin, David L. (1995). 'Workers' compensation and injury duration: evidence from a natural experiment', American Economic Review vol. 85(3), pp. 322-40.

Micklewright, John and Nagy, Gyula (1996). 'Labour market policy and the unemployed in Hungary', European Economic Review vol. 40, pp. 819-28.

Miller, Cynthia, Garfinkel, Irwin and McLanahan, Sara (1994). 'Child support payments: do state policies make a difference?' typescript, July.

Moore, Michael J. and Viscusi, W. Kip (1990). Compensation Mechanisms for Job Risks: Wages, Workers' Compensation and Product Liability, Princeton: Princeton University Press.

Pande, Rohini, (1999). 'Minority representation and policy choices: the significance of legislator identity', typescript.

Pitt, Mark M., Rosenzweig, Mark R. and Gibbons, Donna M. (1993). 'The determinants and consequences of the placement of government programs in Indonesia', World Bank Economic Review vol. 7(3), pp. 319-48.

Poterba, James, (1994). 'State responses to fiscal crises: the effects of budgetary institutions and politics', Journal of Political Economy, vol. 102(4), pp. 799-821.

Poterba, James M., (1996). 'Demographic structure and the political economy of public education', Journal of Policy Analysis and Management, vol. 16(1), pp. 48-66.

Rosenzweig, Mark and Wolpin, Kenneth (1986). 'Evaluating the effects of optimally distributed public programs', American Economic Review, vol. 76(4), pp. 470-82.

Ruhm, Christopher J., (1996). 'The economic consequences of parental leave mandates: lessons from Europe', National Bureau of Economic Research Working Paper 5688 (July).

Rule, W. and Zimmerman, J. (1994). Electoral Systems in Comparative Perspective: Their Impact on Women and Minorities, Westport, CT, Greenwood Press.

Thomas, Sue, (1994). How Women Legislate, New York: Oxford University Press.

Viscusi, W. Kip, (1980). 'Imperfect job risk information and optimal workmen's compensation benefits', Journal of Public Economics, vol. 14, pp. 319-37. 